\title{
Studies on the control of the corpus luteum in the vole, Microtus agrestis
}

\author{
H. M. Charlton, S. R. Milligan* and E. Versi \\ Department of Human Anatomy, South Parks Road, Oxford and *Department of Physiology, \\ University of London Kings College, Strand, London, WC2R $2 L S, U . K$.
}

\begin{abstract}
Summary. The lifespan of corpora lutea resulting from hormonally induced ovulations was prolonged by exogenous prolactin, concurrent lactation, or pregnancy. Treatment of mated females with bromocriptine resulted in failure of luteal function only when the drug was given before Day 6 of pregnancy. Pregnancy was dependent on the presence of the ovaries in its later stages. The results suggest that prolactin is luteotrophic in early pregnancy but that a placental luteotrophin may become effective by Day 6 of pregnancy.
\end{abstract}

\section{Introduction}

The vole, Microtus agrestis, is a reflex ovulator (Austin, 1957; Breed, 1967) but forms fully functional corpora lutea $(\mathrm{CL})$ only after activation of another mechanism separate from that controlling ovulation (Milligan, 1975), thus resembling species like the hamster, mouse and rat in which prolactin is an important part of the luteotrophic hormone complex (Madhwa Raj, MacDonald \& Greep, 1974). That prolactin might also be important in the vole was suggested by the observation that the development of functional $\mathrm{CL}$ following mating was associated with elevated prolactin levels immediately following coitus (Milligan \& MacKinnon, 1976). This role of prolactin in voles was therefore studied in various experiments by injecting the hormone or by inhibiting its secretion.

Placental luteotrophins are believed to be important in the maintenance of CL in other rodent species (Kohmoto \& Bern, 1970; Linkie \& Niswender, 1973; Matthies, 1974) and a placental lactogen has been detected in voles at approximately Day 8 of pregnancy (Forsyth \& Blake, 1976). The production during pregnancy of a luteotrophin other than prolactin was therefore further investigated in the present study, as was the dependence of pregnancy on the continued presence of the ovaries.

\section{Materials and General Methods}

Laboratory-bred voles used in Exps I, II and VII were from the Department of Agricultural Science, Oxford and were maintained as described by Breed (1969). In other experiments, voles from the Department of Human Anatomy, Oxford, were used and these were maintained as described by Worth, Charlton \& MacKinnon (1973). Females were 2- to 3-month-old mature virgins and the stud males were breeding adults. Matings took place between 16:00 and 18:00 h, the male being placed in the cage at least 5 min before the female. After $15 \mathrm{~min}$ of mating activity, the female was separated from the male and kept with other mated females (3-4 to a cage) for the duration of the experiment. A mating was considered successful if a copulatory plug was present.

Injections. These were given either subcutaneously (s.c.) without anaesthetic beneath the skin at the back of the head, or intravenously (i.v.) under ether anaesthesia into the external jugular vein. All injection volumes were $0.1 \mathrm{ml}$. Synthetic LH-RH (ICI, Alderley Edge, Cheshire, U.K., or Hoechst A.G., Frankfurt, W. Germany) was freshly made up in physiological saline $(0 \cdot 154 \mathrm{M}-\mathrm{NaCl})$. The dose used to induce ovulation was $100 \mathrm{ng}$. LH (NIH-LH-S19) was also made up in saline and $10 \mu \mathrm{g}$ were injected s.c. into pregnant females to induce ovulation. Prolactin (NIH-P-S9) was injected s.c. at a dose of 2 i.u. per injection unless otherwise stated. The vehicle was a solution of $3 \mathrm{mg}$ phenol and 50 $\mathrm{mg}$ sucrose per $\mathrm{ml}$ distilled water. Progesterone (Sigma Chemical Co. Ltd, Kingston-upon-Thames, U.K.) was made up in arachis oil and administered s.c. at a dose of $1 \mathrm{mg}$ per injection. Bromocriptine 
(2-bromo- $\alpha$-ergokryptine mesylate: Sandoz, Basle) was given s.c. at a dose of $0.2 \mathrm{mg} /$ injection (except in Exp. VI). The vehicle consisted of $2 \mathrm{mg}$ tartaric acid dissolved in $0.3 \mathrm{ml} 70 \%$ ethanol $+0.7 \mathrm{ml}$ saline. In Exp. VI the dose was $1 \mathrm{mg} /$ injection and the vehicle was $10 \mathrm{mg}$ tartaric acid dissolved in $0.5 \mathrm{ml} 70 \%$ ethanol $+0.5 \mathrm{ml}$ saline.

Operative techniques. Laparotomies were performed under ether anaesthesia and ovaries were examined macroscopically for $C L$ to detect ovulation. Large pink vascularized structures were considered indicative of functional CL and smaller white opaque bodies of degenerating CL (Milligan, 1975). The ability of the CL to support a decidual cell reaction (DCR) was tested in some females by traumatizing one uterine horn by a silk thread insertion. This was performed at $3 \frac{1}{2}$ days after the initial hormone injection and the animals were killed 3 days later.

Autopsy. All ovaries and the uteri were examined macroscopically and then dissected out and fixed in Bouin's fluid for routine histological studies. Sections were stained with Ehrlich's haematoxylin and eosin. Histologically, pink vascularized CL were made up of large polyhedral eosinophilic cells interspersed with an abundance of blood capillaries. These CL were considered to be active. The white opaque bodies contained cells with pyknotic nuclei and a greatly reduced blood supply and were considered to be degenerating. In uteri subjected to trauma, a positive DCR was indicated by the greatly increased size of the horn. Histological studies showed the presence of decidual cells obliterating the uterine lumen. In Exp. V, an ovary was said to possess supernumerary CL if there were 2 size classes of CL of which the number of the larger CL corresponded to the number of embryos in the ipsilateral horn.

Assays. Plasma was stored at $-20^{\circ} \mathrm{C}$ until assayed for $\mathrm{LH}$ and prolactin with a double-antibody radioimmunoassay method as described by Milligan \& MacKinnon (1976). The sensitivities of the assays were $0.25 \mathrm{ng} \mathrm{LH} / \mathrm{ml}$ and $1.95 \mathrm{ng}$ prolactin $/ \mathrm{ml}$ and the intra- and inter-assay coefficients of variance were 10 and $23 \%$ respectively for both assays.

\section{Experimental Methods and Results}

\section{Experiment I. Effect of prolactin on CL induced by $L H-R H$}

Females were given an initial s.c. injection of synthetic LH-RH to induce ovulation and were then subjected to various prolactin treatments (see Table 1). No prolactin was given to Group A; in Group B a single intravenous (i.v.) injection of prolactin ( 8 i.u.) was given immediately after $\mathrm{LH}-\mathrm{RH}$; in Group C 2 i.u. prolactin were given subcutaneously at $6 \mathrm{~h}$ intervals for 24 or $48 \mathrm{~h}$ after LH-RH; and in Group D prolactin was given three times daily for 7 days, the total daily dose being $0 \cdot 5,2$ or 8 i.u. per animal. Animals were killed or laparotomized $3 \frac{1}{2}-4$ days after the LH-RH injection and the ovaries were examined for the presence of vascularized CL.

In Groups $A$ and $D$ the ability of the $C L$ to support a DCR was tested and the animals were killed 7 days after the LH-RH injection. Treatment with LH-RH alone (Group A) resulted in the formation of short-lived CL in all the females that ovulated. Neither an immediate injection of prolactin (Group B) nor repeated injections of this hormone for 24 or $48 \mathrm{~h}$ (Group C) was able to maintain the CL in the majority of animals. However, treatment with prolactin for 7 days prolonged the life of the CL. Only voles in Group D that had been treated continuously with prolactin showed a DCR.

\section{Experiment II. Effect of suckling on CL induced by $L H-R H$}

New-born young were allowed to remain with or were removed from their primiparous mothers. On Day 5 after parturition all females were injected with LH-RH. They were laparotomized $3 \frac{1}{2}$ days later and the ovaries were examined macroscopically for luteal structures. The uteri were traumatized and all the females were killed after a further 3 days ( $11 \frac{1}{2}$ days after parturition).

Six out of 10 of the females which had had their litters removed at birth ovulated in response to the LH-RH treatment. CL were maintained and able to support a DCR in only one of these 6; in others the CL were degenerating 3 days after injection. Six out of 8 females suckling their young ovulated after LH-RH; 3 days later all 6 possessed CL that were able to support a DCR. 
Table 1. The effect of exogenous prolactin on the function of CL in voles induced to ovulate by injection of $100 \mathrm{ng}$ LH-RH (Exp. I)

\begin{tabular}{|c|c|c|c|c|c|}
\hline Group & Treatment & $\begin{array}{l}\text { No. of } \\
\text { females }\end{array}$ & $\begin{array}{c}\text { Females with } \\
\text { degenerating CL } \\
\text { at Day } 3 \frac{1}{2} \\
(\%)\end{array}$ & $\begin{array}{c}\text { Females with } \\
\text { vascularized } \\
\text { CL at Day } 3 \frac{1}{2} \\
(\%)\end{array}$ & $\begin{array}{c}\text { Females with } \\
\text { DCR } \\
(\%)\end{array}$ \\
\hline A & LH-RH & 6 & 100 & 0 & 0 \\
\hline B & $\begin{array}{l}\text { LH-RH + immediate } \\
\text { prolactin }\end{array}$ & 10 & 90 & 10 & Not tested \\
\hline $\mathrm{C}$ & LH-RH + prolactin for & 6 & 83 & 17 & Not tested \\
\hline D & $\begin{array}{l}48 \mathrm{~h} \\
\text { LH-RH }+7 \text { days of: }\end{array}$ & 10 & 90 & 10 & Not tested \\
\hline & $\begin{array}{l}\text { saline } \\
0.5 \text { i.u. prolactin/day }\end{array}$ & $\begin{array}{l}4 \\
4\end{array}$ & $\begin{array}{r}100 \\
0\end{array}$ & $\begin{array}{c}0 \\
100\end{array}$ & $\begin{array}{c}0 \\
75^{*}\end{array}$ \\
\hline & 2 i.u. prolactin/day & 4 & 0 & 100 & 100 \\
\hline & 8 i.u. prolactin/day & 4 & $\mathbf{0}$ & 100 & 100 \\
\hline
\end{tabular}

* The animal in this group that did not support a DCR possessed degenerating CL and had a cornified vaginal smear at autopsy.

\section{Experiment III. Effect of bromocriptine on postcoital LH and prolactin levels}

Females with cornified smears were given a single s.c. injection of $0.2 \mathrm{mg}$ bromocriptine or the vehicle solution and were mated $12 \mathrm{~h}$ later. At $15 \mathrm{~min}$ after mating had begun they were bled from the external jugular and the plasma was assayed for $\mathrm{LH}$ and prolactin concentrations. The results are shown in Table 2.

Prolactin levels after bromocriptine treatment were significantly lower than control values but there were no significant differences in LH levels between control and experimental groups.

Table 2. Effect (mean \pm s.e.m.) of bromocriptine on postcoital LH and prolactin levels (Exp. III)

\begin{tabular}{lccc}
\hline \multicolumn{1}{c}{ Treatment } & No. of animals & LH $(\mathrm{ng} / \mathrm{ml})$ & Prolactin $(\mathrm{ng} / \mathrm{ml})$ \\
\hline Bromocriptine & 10 & $39 \cdot 9 \pm 6 \cdot 8$ & $13.0 \pm 1 \cdot 1^{*}$ \\
Control & 5 & $51 \cdot 9 \pm 16.0$ & $25.0 \pm 3 \cdot 3$ \\
\hline
\end{tabular}

* Compared with control group, $P<0.01$ (Mann-Whitney U test).

\section{Experiment $I V$. Effect of bromocriptine on $C L$ induced by mating}

Group A. Females were treated with bromocriptine, or the vehicle solution, at different stages of pregnancy. All animals were killed 3 days after the start of treatment which consisted of four s.c. injections, $8 \mathrm{~h}$ apart starting at 16:00 h.

Voles injected with bromocriptine on or before Day 5 of pregnancy had degenerating CL (Table 3). In contrast, functional $\mathrm{CL}$ were maintained in most of the females receiving the vehicle injection only. From Day 6 onwards a small percentage of bromocriptine-treated animals exhibited degenerating CL but there was no statistically significant difference between the control and experimental groups, suggesting that the drug is not effective after Day 5.

Group B. Females were treated on Day 2 of pregnancy as follows: (a) with bromocriptine as in Group A; (b) as in (a) but 4 s.c. injections of prolactin ( 2 i.u./injection) were given concomitantly; (c) as in (b) but with a further 2 injections of prolactin $8 \mathrm{~h}$ apart; (d) as in (c) but with the vehicle for prolactin. All animals in this group were killed on Day 6. Day-2 pregnant females treated with bromocriptine alone (a) or in combination with the prolactin vehicle (d) all had degenerating CL. Degenerating CL were also present in 7 out of 9 females given 4 injections of prolactin with bromocriptine (b). 
Table 3. Effect of bromocriptine on the CL of voles (nos in parentheses) induced to ovulate by mating (as \% of animals with degenerating CL: Exp. IVA)

\begin{tabular}{|c|c|c|c|c|c|c|c|c|c|c|c|}
\hline & \multicolumn{11}{|c|}{ Day of pregnancy } \\
\hline & 0 & 2 & 4 & 5 & 6 & 8 & 10 & 12 & 14 & 16 & 17 \\
\hline Bromocriptine & $\begin{array}{l}100^{*} \\
(8)\end{array}$ & $\begin{array}{c}100^{*} \\
(9)\end{array}$ & $\begin{array}{l}100^{*} \\
\text { (11) }\end{array}$ & $\begin{array}{c}100^{*} \\
(8)\end{array}$ & $\begin{array}{l}27 \cdot 3 \\
(11)\end{array}$ & $\begin{array}{r}20 \\
(10)\end{array}$ & $\begin{array}{r}30 \\
(10)\end{array}$ & $\begin{array}{r}10 \\
(10)\end{array}$ & $\begin{array}{l}20 \\
(5)\end{array}$ & $\begin{array}{l}25 \\
(4)\end{array}$ & $\begin{array}{r}8 \cdot 3 \\
(12)\end{array}$ \\
\hline Vehicle only & $\begin{array}{r}0 \\
(6)\end{array}$ & $\begin{array}{r}0 \\
(6)\end{array}$ & $\begin{array}{l}15 \cdot 4 \\
(13)\end{array}$ & $\begin{array}{r}0 \\
(7)\end{array}$ & $\begin{array}{r}0 \\
(9)\end{array}$ & $\begin{array}{r}0 \\
(10)\end{array}$ & $\begin{array}{r}0 \\
(5)\end{array}$ & $\begin{array}{r}22 \cdot 2 \\
(9)\end{array}$ & $\begin{array}{l}20 \\
(5)\end{array}$ & $\begin{array}{r}16 \cdot 7 \\
(6)\end{array}$ & $\begin{array}{c}0 \\
\text { (7) }\end{array}$ \\
\hline
\end{tabular}

* Compared with control group, $P<0.001$ (Exact probability test).

However, all 6 females given the extra injections of prolactin (c) possessed histologically healthy CL. In animals with degenerating CL there was no sign of implanted embryos whereas in those with healthy $\mathrm{CL}$ the number of embryos implanted corresponded to the number of $\mathrm{CL}$ in the ipsilateral ovary.

Group C. Day-5 pregnant females were treated in the same way as the voles in Groups B(a) and B(b).

Degenerating CL were found in all 8 females given bromocriptine alone, but 6 out of 7 females given only 4 injections of prolactin with bromocriptine had histologically healthy CL. Those animals with degenerating $\mathrm{CL}$ were resorbing their embryos.

\section{Experiment $V$. Effect of concurrent pregnancy on $C L$ induced by $L H$}

Experimental animals were allowed to mate, but controls were placed with active males for 5 min during which time foreplay, but not intromission, was permitted. After this exposure to the male, the controls were given a s.c. injection of an ovulatory dose of LH-RH.

Group $A .3$ days after the beginning of the experiment, mated and control females were given a single s.c. injection of $10 \mu \mathrm{g} \mathrm{LH}$. They were killed 3 days later (Day 6) and their ovaries examined. Four out of 5 of the Day-3 pregnant females ovulated in response to the LH injection, as indicated by the presence of supernumerary $\mathrm{CL}$ at autopsy. None of the CL were degenerating. In contrast, all 5 of the control females had degenerating CL (Exact probability test, $P<0 \cdot 01$ ).

Group $B$. Mated and control females were similarly treated with $\mathrm{LH}$ but 8 days after the beginning of the experiment. These animals were killed on Day 11 and their ovaries examined. Five out of 6 pregnant females produced supernumerary CL in response to $\mathrm{LH}$ and $\mathrm{CL}$ in all pregnant animals were histologically healthy. All 4 of the control females had degenerating CL at this time (Exact probability test, $P<0.01$ ).

Group $C$. Mated females were treated in the same way as those in Group B, but were also given 6 injections of bromocriptine at $8 \mathrm{~h}$ intervals starting at 24:00 h on Day 7 after mating, i.e. the last injection of bromocriptine was given $24 \mathrm{~h}$ after the LH injection. All 4 animals ovulated in response to the $\mathrm{LH}$ injection producing supernumerary $\mathrm{CL}$ and none of the $\mathrm{CL}$ were degenerating at autopsy.

\section{Experiment VI. Effect of bromocriptine on CL of pregnancy and pseudopregnancy}

Pseudopregnancy was induced by mating with males which had been vasectomized 3 months previously. Day-6 pregnant and pseudopregnant animals were treated with a single s.c. injection of bromocriptine $(1 \mathrm{mg})$ or the vehicle solution at 18:00 h. All animals were killed $24 \mathrm{~h}$ later and the ovaries examined.

All of the pregnant animals given bromocriptine (3) or the vehicle solution (3) had histologically healthy CL and embryos at autopsy. In contrast all of the pseudopregnant animals (5) treated with bromocriptine had degenerating CL at autopsy (Exact probability test, $P<0.05$ ). Only 1 out of 4 pseudopregnant females treated with the vehicle solution had degenerating CL.

\section{Experiment VII. Effect of ovariectomy and progesterone replacement in late pregnancy}

Four females were ovariectomized or sham-operated on each of Days 15, 16, 17 and 18 of pregnancy. All spayed females aborted within $24 \mathrm{~h}$ of the operation whereas sham-operated females main- 
tained their fetuses to term (20-21 days). Four females were ovariectomized on Day 15 of pregnancy and treated for 5 days with $1 \mathrm{mg}$ progesterone. All these females maintained their fetuses for the duration of the injections.

\section{Discussion}

The lifespan of CL resulting from LH-RH-induced ovulations can be prolonged by exogenous prolactin for the duration of the hormone treatment (Exp. I), suggesting that prolactin can be luteotrophic in the vole. A high titre of prolactin may be expected in lactating females if this hormone is released in response to suckling and its presence may be expected in early pregnancy if prolactin is part of the initial luteotrophic complex (Milligan \& MacKinnon, 1976). In both these situations hormonally induced CL were maintained (Exps II and VA).

The ergot alkaloid bromocriptine is thought to inhibit prolactin secretion in the rat (Flückiger \& Wagner, 1968), mouse (Yanai \& Nagasawa, 1970), hamster (Ford \& Yoshinga, 1975), goat (McMurtry \& Malven, 1974), sheep (Niswender, 1974), cow (Karg, Schams \& Reinhart, 1972) and man (del Pozo, Brun del Re, Vargo \& Friesen, 1972) by acting primarily at the level of the pituitary (del Pozo \& Flückiger, 1973; Flückiger, Markó, Doepfner \& Niederer, 1976). In voles a profile of prolactin secretion has not been determined but it is known that immediately following mating there is a prolactin surge (Milligan \& MacKinnon, 1976). Bromocriptine given before mating significantly depressed plasma prolactin levels but did not affect the postcoital LH surge (Exp. III). The abortifacient action of this drug when administered before Day 6 of pregnancy (Exp. IVA) could therefore be due to suppression of prolactin secretion. The reversal of the effect of bromocriptine by prolactin administration (Exp. IVB) suggests that bromocriptine may suppress prolactin secretion rather than act directly upon the ovary, as has been suggested for the rat (Zeilmaker \& Carlsen, 1962; Shelesnyak \& Barnea, 1963; Lindner \& Lamprecht, 1970). The evidence from the experiments quoted above argues for a physiological role for prolactin in the normal maintenance of vole CL during early pregnancy.

Although the continued presence of the ovaries would appear to be indispensable in late pregnancy in the vole (Exp. VII), the fact that bromocriptine does not have a significant effect on and after Day 6 (Exp. IVA) argues for the presence of a luteotrophic substance other than prolactin. Circumstantial evidence for this comes from the results of Exp. VC in which LH-induced supernumerary $\mathrm{CL}$ were formed and maintained in 8-day pregnant animals even though they were treated with bromocriptine before and after the LH injection. That another luteotrophic substance may replace prolactin around Day 6 is also indicated by the results of those experiments in which Day-2 pregnant females required 6 injections of prolactin to reverse the effects of bromocriptine (Exp. IVB) whereas Day-5 pregnant females required only 4 prolactin injections (Exp. IVC).

Implantation occurs on Day 4 in Microtus agrestis (Milligan, 1974). The finding that pseudopregnant, but not pregnant, voles had degenerating CL when treated with bromocriptine on Day 6 (Exp. VI) would suggest that the newly formed feto-placental unit may be the origin of the other luteotrophin.

Forsyth \& Blake (1976) have detected a placental lactogen at approximately Day 8 of pregnancy; the present studies indicate that this lactogen may be active much earlier. Kohmoto \& Bern (1970) have demonstrated the presence of a placental lactogen as early as Day 6 of pregnancy in the mouse (vaginal plug $=$ Day 0 of pregnancy).

Although the vole is an induced ovulator, the hormonal control of CL seems to resemble that of spontaneously ovulating myomorphs. Morishige \& Rothchild (1974), using ergocornine (an alkaloid similar to bromocriptine), showed that pregnancy was terminated if the drug was given to rats on or before Day 6 (Day $1=$ day of insemination). The effect of the drug was beginning to wane by Day 7 and was ineffective on Day 8, and prolactin, but not LH or FSH, reversed its action. Ford \& Yoshinaga (1975) showed that bromocriptine terminated pregnancy in the hamster when administered on Day 5, that the drug was less effective on Day 6 and ineffective on Day 7 (Day $1=$ spermatozoa in vagina), and that prolactin but not $\mathrm{LH}$ or FSH reversed the action of the drug. In rats and hamsters the placenta is thought to produce a luteotrophin in late pregnancy (Linkie \& Niswender, 1973; Matthies, 1974). 
We should like to thank Mrs Shirley Lewis and Mrs Lesley Clifford for technical assistance and Mr R. Laynes for carrying out the LH and prolactin assays. The bromocriptine was a gift from Professor Flückiger (Sandoz Pharmaceuticals, Basle); LH-RH was provided by Hoechst Pharmaceuticals and by Dr Gregory (ICI); and the prolactin and LH were supplied by the NIAMDD. Financial assistance from the M.R.C. has been given in the form of grants to H.M.C. and S.R.M. and of a studentship to E.V.

\section{References}

Austin, C.R. (1957) Oestrus and ovulation in the field vole (Microtus agrestis). J. Endocr. 15, iv.

Breed, W.G. (1967) Ovulation in the genus Microtus. Nature, Lond. 214, 826.

BREed, W.G. (1969) Oestrus and ovarian histology in the lactating vole (Microtus agrestis). J. Reprod. Fert. 18, 33-42.

del Pozo, E. \& Flückiger, E. (1973) Prolactin inhibition: experimental and clinical studies. In Human Prolactin, pp. 291-301. Eds J. L. Pasteels \& C. Robyn. Excerpta Medica, Amsterdam.

del Pozo, E., Brun del Re, E., Vargo, L. \& Friesen, H. (1972) The inhibition of prolactin secretion in man by CB154 (2-Br- $\alpha$-ergocryptine). J. clin. Endocr. Metab. 35, 768-771.

Flǘckiger, E. \& WAGNER, H.R. (1968) 2-Br- $\alpha$-Ergocryptine: Beimflussung von Fertilitat und Laktation bei der Ratte. Experientia 24, 1130-1131.

Flückjger, E., Markó, M., Doeprner, W. \& Niederer, W. (1976) Effect of ergot alkaloids on the hypothalamic-pituitary axis. Postgrad. med. J. 52, Suppl. 1, 57-61.

Ford, J.J. \& Yoshinaga, K. (1975) Ergocryptine and pregnancy maintenance in hamsters. Proc. Soc. exp. Biol. Med. 150, 425-427.

Forsyth, I.A. \& BLAKE, L.A. (1976) Placental lactogen (chorionic mammotrophin) in the field vole, Microtus agrestis, and the bank vole, Clethrionomys glareolus. J. Endocr. 70, 19-23.

KaRG, H., Schams, D. \& Reinhart, V. (1972) Effects of 2-Br- $\alpha$-ergocryptine on plasma prolactin level and milk yield in cows. Experientia 28, 574-576.

KoHmoto, K. \& BeRN, H.A. (1970) Demonstration of mammotrophic activity of the mouse placenta in organ culture and by transplantation. J. Endocr. 48, 99-107.

LINDNER, H.R. \& LAMPRECHT, S.A. (1970) Mechanisms of luteolysis: prolactin and the enzymatic inactivation of progesterone in the corpus luteum of the rat. $A d v$. Biosci. 4, 419-426.

LINKIE, D.M. \& NiSWENDER, G.D. (1973) Characterization of rat placental luteotropin. Physiological and physiochemical properties. Biol. Reprod.8, 48-57.

Madhwa RaJ, H.G., MacDonald, G.J. \& Greep, R.O. (1974) Role of luteinizing hormone and prolactin in the luteotropic process. In Gonadotropins and Gona- dal Function, pp. 271-280. Ed. N. R. Moudgal. Academic Press, New York.

Matthies, D. (1974) Placental peptide hormones affecting fetal nutrition and lactation. Effects of rodent chorionic mammotrophin. In Lactogenic Hormones, Fetal Nutrition, and Lactation, pp. 297-334. Eds J. B. Josimovich, M. Reynolds \& E. Cobo. Wiley, New York.

MCMurtry, J.P. \& Malven, P.V. (1974) Experimental alterations of prolactin levels in goat milk and blood plasma. Endocrinology 95, 559-556.

Milligan, S.R. (1974) Some aspects of reproduction in the female vole, Microtus agrestis. D. Phil. thesis, University of Oxford.

MilligaN, S.R. (1975) Mating, ovulation and corpus luteum function in the vole, Microtus agrestis. $J$. Reprod. Fert. 42, 35-44.

Milligan, S.R. \& MacKinnon, P.C.B. (1976) Correlation of plasma $\mathrm{LH}$ and prolactin levels with the fate of the corpus luteum in the vole, Microtus agrestis. $J$. Reprod. Fert. 47, 111-113.

MORISHIGE, W.K. \& ROTHCHILD, I. (1974) Regulation of corpus luteum function by $\mathbf{L H}$, prolactin and placental luteotrophin during the first half of pregnancy in the rat. Endocrinology 95, 260-274.

NisWENDER, G.D. (1974) Influence of 2-Br- $\alpha$-ergocryptine on serum levels of prolactin in the estrous cycle in sheep. Endocrinology 94, 612-615.

Shelesnyax, M.C. \& BARNEA, A. (1963) Studies on the mechanism of ergocornine (ergotoxine) interference with decidualization and nidation. II. Acta endocr., Copenh. 43, 469-476.

Worth, R.W., Charlton, H.M. \& Mackinnon, P.C.B. (1973) Field and laboratory studies on the control of luteinizing hormone secretion and gonadal activity in the vole, Microtus agrestis. J. Reprod. Fert., Suppl. 19, 89-99.

YANAI, R. \& NAGASAWA, H. (1970) Suppression of mammary hyperplastic nodule formation and pituitary prolactin secretion in mice induced by ergocornine or 2-bromo- $\alpha$ ergocryptine. J. natn. Cancer Inst. 45, 1105-1112.

Zellmaker, G.H. \& CARlsen, R.A. (1962) Experimental studies on the effect of ergocornine methanesulphonate on the luteotrophic function of the rat pituitary gland. Acta endocr., Copenh. 41, 321-335. 